ISSN 1392-3196 / e-ISSN 2335-8947

Zemdirbyste-Agriculture, vol. 100, No. 4 (2013), p. 401-408

DOI $10.13080 /$ z-a.2013.100.051

\title{
Dynamics of spread and control of cercospora (Cercospora beticola Sacc.) and ramularia (Ramularia beticola Fautrey \& F.Lamb.) leaf spot in sugar beet crops
}

\author{
Milda BALTADUONYTÉ ${ }^{1}$, Zenonas DABKEVIČIUSS ${ }^{1,2}$, Zita BRAZIENË ${ }^{2}$, \\ Elena SURVILIENE $\dot{E}^{2}$ \\ ${ }^{1}$ Aleksandras Stulginskis University \\ Studentų 11, Akademija, Kaunas distr., Lithuania \\ E-mail: baltaduonyte.m@gmail.com \\ ${ }^{2}$ Lithuanian Research Centre for Agriculture and Forestry \\ Instituto 1, Akademija, Kèdainiai distr., Lithuania
}

\begin{abstract}
Dynamics of spread of the most destructive sugar beet foliar diseases cercospora (Cercospora beticola Sacc.) and ramularia (Ramularia beticola Fautrey \& F.Lamb.) leaf spot and efficacy of six fungicides used for their control were investigated at Rumokai Research Station of Lithuanian Research Centre for Agriculture and Forestry during 2011-2012. The crop was sprayed with fungicides once after the first symptoms of foliar diseases had been spotted. In the experimental years, cercospora leaf spot started to spread in the sugar beet crops on the $31^{\text {st }}$ of July $-3^{\text {rd }}$ of August. During the $1^{\text {st }}$ assessment the disease incidence was $4.3-19.2 \%$ and the disease severity was $0.01-0.08 \%$. Further progress of cercospora leaf spot was influenced by the weather conditions: with the weather being wet and warm the disease development was rapid and 10-11 weeks after the $1^{\text {st }}$ assessment the disease incidence reached $90.0-98.3 \%$, and the disease severity was $10.98-11.91 \%$. Ramularia leaf spot started to spread at the same time as cercospora leaf spot; however, its severity was lower. The progress of ramularia leaf spot was weaker than that of cercospora leaf spot and before harvesting ramularia leaf spot severity reached $1.75-1.79 \%$.

The highest efficacy against both diseases was exhibited by the fungicides containing epoxiconazole - Maredo, Opera N, Tango super.
\end{abstract}

Key words: Cercospora beticola, fungicides, Ramularia beticola, root yield, sugar beet, sugar yield.

\section{Introduction}

Recently, the sugar beet production area has been increasing in Lithuania: in 2011 it was 17.6 thousand ha in 2012 - 19.2 thousand ha (Statistics Lithuania, 2012). Increasing sugar beet area, shorter crop rotations have resulted in intensive spread of fungal foliar diseases. Foliar fungal diseases that spread in sugar beet crops are: cercospora leaf spot (causal pathogen - Cercospora beticola Sacc.), ramularia leaf spot (Ramularia beticola Fautrey \& F.Lamb.), phoma leaf spot (Pleospora betae Björl.), powdery mildew (Erysiphe betae Vaňha Weltzien), beet rust (Uromyces beticola (Bellynck) Boerema, Loer. \& Hammers), alternaria leaf spot (Alternaria alternata (Fr.) Keissl). The most common and damaging sugar beet diseases in Lithuania are cercospora leaf spot and ramularia leaf spot (Gaurilčikienè et al., 2006). Cercospora leaf spot is one of the most important and destructive fungal diseases of sugar beet in many countries of the world (Wolf, Verreet, 2002; Weiland, Koch, 2004; Jacobsen, Franc, 2009). The disease was first reported in 1876; however, only in 1953 its causal pathogen was identified by the American researchers (Weiland, Koch, 2004). In the regions of warm and wet climate, cercospora leaf spot damages more than $30 \%$ of the sugar beet crops. Severe epidemics of this disease occurred in the $9^{\text {th }}-10^{\text {th }}$ decades of the $20^{\text {th }}$ century in Austria, Bulgaria, Bosnia and Herzegovina, Southern France, Italy, the USA and other countries (Asher, Hanson, 2006).

Ramularia leaf spot is distributed in the regions of a cooler and wetter climate - Northern and Eastern Europe, North America, Western Canada, and Russia. The disease can be devastating if it starts spreading in sugar beet crops early (in July - beginning of August). Ramularia leaf spot can cause white sugar yield losses of up to $24 \%$ (Petersen et al., 2001). In the diseased leaves the processes of photosynthesis and assimilation are weak, the concentrations of nitrogen, phosphorus, potassium and soluble carbohydrates decline, root yield reduces and root quality deteriorates (Boten, Šikalčik, 2001). When leaves are severely diseased, plants start to intensively produce new leaves by using the accumulated organic matter, which results in a significant reduction in 
root sugar content (Vereijssen et al., 2003). The incidence and development of diseases are promoted by excessive nitrogen, high plant population density, continuous cropping, increased sugar beet residues in the soil, and ploughless soil tillage (Khan et al., 2008).

Fungal diseases cause reduction of sugar beet root yield and sugar content, damaged roots exhibit poor storability in clamps. If sugar beet leaves are severely affected by diseases, root yield losses can range from $10 \%$ to $30 \%$, in extreme cases to $50 \%$ and more (Wolf, Verreet, 2002). The climate warming, shorter crop rotations, increasing soil compaction favour the occurrence of fungal diseases. To prevent the spread of fungal diseases it is of major importance to employ adequate crop and soil management practices such as optimal sugar beet share in a crop rotation, suitable pre-crops, good soil structure, timely and well-balanced fertilization, early sowing, choice of disease-resistant cultivars, destruction of disease causal agents and intermediate hosts (Vereijssen et al., 2005; Gaurilčikienè et al., 2006).

However, chemical control of diseases is still the most common practice employed by growers (Wolf, Verreet, 2002; Bălău, Irimia, 2010). Since 1990, with the advent of new groups of fungicides (triazoles and strobilurines), the range of active ingredients intended for the control of foliar diseases has been expanded (Barlett et al., 2002; Karaoglanidis, Bardas, 2006). Cercospora leaf spot, which is the most widespread fungal foliar disease of sugar beets is currently controlled by benzimidazoles, morpholine, strobilurines and dithiocarbomates (Khan, Smith, 2005; Asher, Hanson, 2006). In chemical plant protection, the proper choice of a fungicide, its dose rate and application timing are crucial factors. Biological efficacy of fungicides has been found to be influenced by the disease severity at application (Braziene, 2011). With a proper timing of spray applications, one can reduce the number of applications per season, which in turn reduces sugar beet cultivation costs, prevents from the development of resistance to active ingredients, inhibits the build up of causal pathogens of diseases and reduces environmental pollution (Vereijssen, 2007). The use of the same active ingredients for an extended period of time can result in fungicide resistance development in plant pathogens. In the USA and Australia there were found Cercospora beticola races resistant to triphenyltin hydroxide (TPTH) and strobilurines (Briere et al., 2003; Malandrakis et al., 2011). Cercospora beticola sensitivity to dithiocarbomates, benzimidazoles and triazoles fungicides class has also been noted to be decreasing (Briere et al., 2003; Weiland, Koch, 2004; Karaoglanidis, Ioannidis, 2010). In order to prevent resistance of plant pathogens to the chemical ingredient used, it is recommended to use fungicides containing different active ingredients to successfully control disease progress and reduce sugar yield losses (Secor et al., 2010). Six fungicides belonging to triazoles, azoles, strobilurines, morpholine classes are currently allowed to be used in sugar beet crops in Lithuania.

The present study was aimed to explore the spread and dynamics of foliar fungal diseases in unsprayed and fungicide sprayed sugar beet crops, to establish the efficacy of six fungicides used and their effect on sugar beet root yield and quality.

\section{Materials and methods}

Research into the incidence and control of cercospora (Cercospora beticola Sacc.) and ramularia (Ramularia beticola Fautrey \& F.Lamb.) leaf spot in sugar beet crops was conducted during 2011-2012 at Rumokai Research Station of Lithuanian Research Centre for Agriculture and Forestry. The soil of the experimental site is Haplic-Epihypogleyic Luvisol ( $L V g-p-w-h a)$, with a texture of moderately heavy loam. The study involved the sugar beet variety 'Ernestina', which is widely cultivated in Lithuania and is susceptible to leaf diseases. The pre-crop was winter wheat. The crop was sown in the second half of April with a drill at a sowing density of 6-7 pelleted seeds per longitudinal meter with a $45 \mathrm{~cm}$ interrow width. The sugar beet was grown in compliance with the recommendations of Lithuanian Institute of Agriculture (Deveikyte et al., 2009). To control weeds, the crops were sprayed three times during the growing season with the following herbicides: Betanal Expert (active ingredient (a.i.) fenmediphan $91 \mathrm{~g} \mathrm{l}^{-1}$, desmedipham $71 \mathrm{~g} \mathrm{l}^{-1}$, ethofumesate $112 \mathrm{~g} \mathrm{l}^{-1}$; at a rate of $\left.1.001 \mathrm{ha}^{-1}\right)+$ Goltix (a.i. metamitron $700 \mathrm{~g} \mathrm{l}^{-1}$, at a rate of $1.00 \mathrm{l} \mathrm{ha}^{-1}$ ), Betanal Expert (at a rate of $1.251 \mathrm{ha}^{-1}$ ), Betanal Expert (at a rate of $1.25 \mathrm{l} \mathrm{ha}^{-1}$ ) + Nortron (a.i. ethofumesate $500 \mathrm{~g} \mathrm{l}^{-1}$; at a rate of $0.31 \mathrm{ha}^{-1}$ ) and to control pests insecticide Proteus (a.i. thiacloprid $100 \mathrm{~g} \mathrm{l}^{-1}$, deltamethrin $10 \mathrm{~g} \mathrm{l}^{-1}$ at a rate of $0.751 \mathrm{ha}^{-1}$ ) was used.

The experiment was laid out in four replications. The plots were arranged in a systematic order. The total plot size was $12 \mathrm{~m} \times 2.7 \mathrm{~m}=32.4 \mathrm{~m}^{2}(6$ rows $12 \mathrm{~m}$ in length), the harvested plot size was $18 \mathrm{~m}^{2}$.

The following fungicides were used in the study: Bumper super (triazole, a.i. prochloraz $400 \mathrm{~g} \mathrm{l}^{-1}$ + propiconazole $90 \mathrm{~g} \mathrm{l}^{-1}$ ) at a rate of 1,0 $1 \mathrm{ha}^{-1}$, Folicur (triazole, a.i. tebuconazole $250 \mathrm{~g} \mathrm{l}^{-1}$ ) $-1,01 \mathrm{ha}^{-1}$, Impact (triazole, a.i. flutriafol $250 \mathrm{~g} \mathrm{l}^{-1}$ ) $-0.251 \mathrm{ha}^{-1}$; Maredo (triazole, a.i. epoxiconazole $125 \mathrm{~g} \mathrm{l}^{-1}$ ) $-1.0 \mathrm{l} \mathrm{ha}^{-1}$, Opera $\mathrm{N}$ (strobilurines + triazole, a.i. pyraclostrobin $85 \mathrm{~g} \mathrm{l}^{-1}$ + epoxiconazole $62,5 \mathrm{~g} \mathrm{l}^{-1}$ ) $-0.8 \mathrm{l} \mathrm{ha}^{-1}$, Tango super (morpholine + triazole, a.i. fenpropimorph $250 \mathrm{~g} \mathrm{l}^{-1}+$ epoxiconazole $84 \mathrm{~g} \mathrm{l}^{-1}$ ) $-1.51 \mathrm{ha}^{-1}$. For the current study, we chose the fungicides, most commonly used by sugar beets growers and the newly recommended ones.

The spray application was made when foliar fungal diseases had damaged about $5 \%$ of the plants (in 2011 on 3 August, in 2012 on 1 August). Assessments of foliar fungal diseases were done in record plots in 4 places per plot on 5 plants in a row (20 plants per plot). Percentage (\%) of damaged plants and disease-affected leaf area per plant were estimated. Healthy leaves and those affected by different foliar fungal diseases were counted. Disease severity was estimated by establishing the disease-affected leaf area in per cent, according to the scale: $0,1,1,2,5,10,25,35,45$ and 60 (EPPO Standards, 2004). Assessments of disease prevalence were done six times, before application and continued every 2-3 weeks.

Disease severity $(\mathrm{R})$ was calculated according to the formula:

$$
\mathrm{R}=\frac{\Sigma(n \cdot b)}{N} \text {, where } n \text { is same grade or percentage }
$$

of damaged leaf number, $b$ - damage values, $\mathrm{N}$ - number of leaves of checked plants. 
Biological efficacy of the fungicides (X) was calculated according to Abbott's formula (Korol, Preičerzon, 1990):

$\mathrm{X}=\frac{a-b}{a} \cdot 100$, where $\mathrm{a}$ is disease severity in the control treatment, $\mathrm{b}$ - disease severity in the fungicideapplied treatment.

The sugar beet crop was harvested on 19 October in 2011 and on 13 October in 2012. Root and leaf yield was determined and root samples were taken for laboratory analyses. Analyses were performed at the laboratory of AB Nordic Sugar Kedainiai. Sugar content was determined (cold digestion method), potassium, sodium (flame photometry), $\alpha$-amino $\mathrm{N}$ (colorimetrically) and white sugar yield was calculated (Dutton, Huijbregts, 2006).
Weather conditions. The dry and warm weather in the $3^{\text {rd }}$ ten-day period of April in 2011 was favourable for sugar beet sowing; however, after sowing, the weather turned cool and frequent frosts occurred, which made this period adverse for crop emergence and establishment (Fig. 1). The beginning of June was hot and dry, but the rainfall which fell later improved the growing conditions. July and August were warm and rainy. The conditions were conducive not only to sugar beet growth but also to the spread of diseases. September was warm with no frosts; however, dull weather with little sunshine (193.3 hours of sunshine per month) was not favourable for sugar accumulation in roots.
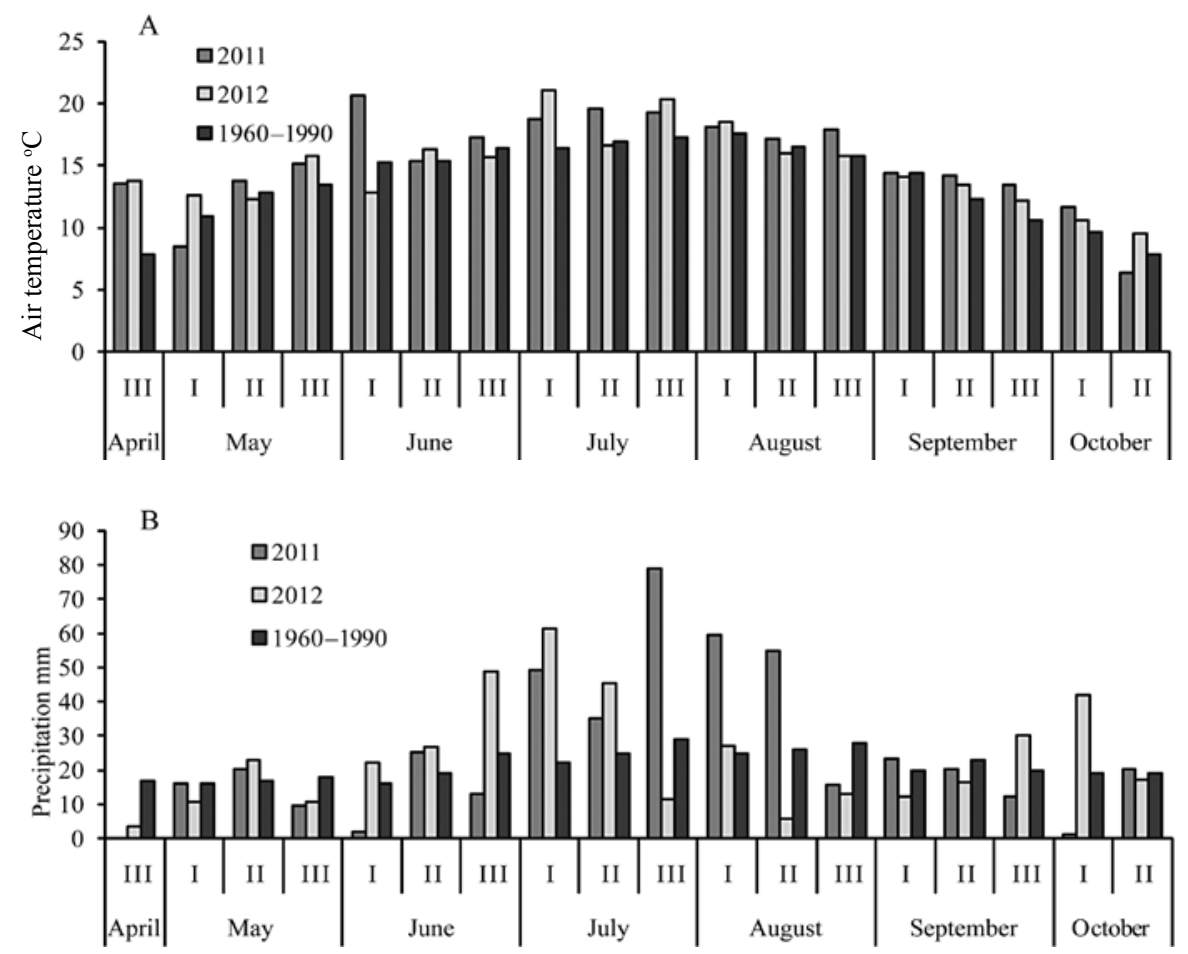

Figure 1. Average daily air temperature (A) and amount of precipitation (B) during the sugar beet growing season in 2011-2012 and climate normal (1961-1990)

\section{Kybartai Weather Station}

In 2012, the weather during the end of April beginning of May was warm and favourable for sugar beet emergence. The air temperature of May and June was close to that of climate normal. The amount of rainfall at the end of June - beginning of July markedly exceeded the climate normal. In August, the amount of rainfall was only half of the normal rate; however, the weather was overcast and wet, therefore the plants did not feel any shortage of moisture. In September, warm and dry weather was conducive to root growth and sugar accumulation: the average daily temperature was $+13.3^{\circ} \mathrm{C}$, without any considerable variation, the sunshine was 235.0 hours per month, and the monthly amount of rainfall was $59.1 \mathrm{~mm}$.

The data were statistically estimated using analysis of variance method from software ANOVA. The significant differences between the means (the control and individual treatments) were established by the least significant difference at a significance levels of $P \leq 0.05$ and $P \leq 0.01$ (Tarakanovas, Raudonius, 2003).

\section{Results and discussion}

Cercospora leaf spot and ramularia leaf spot were the most devastating diseases in sugar beet crops during the research period. Other foliar diseases such as phoma leaf spot and powdery mildew were also present in the tested crops; however, their severity was very low $0.93 \%$ and $0.69 \%$, respectively.

Cercospora leaf spot. In 2011, on 3 August (the $1^{\text {st }}$ assessment), before the fungicide spray application, the disease-affected plants accounted for 5.8-19.2\%, the disease severity was low $0.01-0.08 \%$ (Fig. 2). The August weather was very conducive to cercospora leaf spot development: average daily temperature was higher than climate normal and there was enough moisture because of the rain and overcast days. A strong positive relationship $(r=0.75)$ was established between cercospora leaf spot severity and August's average daily temperature and rainfall (Petkevičienè, Kaunas, 2004). During the $2^{\text {nd }}$ assessment (on 24 August) cercospora leaf 
spot severity in the plots not sprayed with fungicides was much higher and amounted to $0.34 \%$. In the fungicideapplied plots, the severity of this disease ranged from $0.12 \%$ to $0.23 \%$. A month after fungicide application, cercospora leaf spot severity was $1.66 \%$ in the control plots, and in fungicide-applied plots it was $0.19-0.85 \%$. The lowest disease severity was established in the plots sprayed with the fungicide Maredo. Cercospora leaf spot rapidly developed in September and first half of October. In unsprayed plots before harvesting, $98.3 \%$ of plants were found to be damaged and the disease severity was as high as $10.98 \%$.

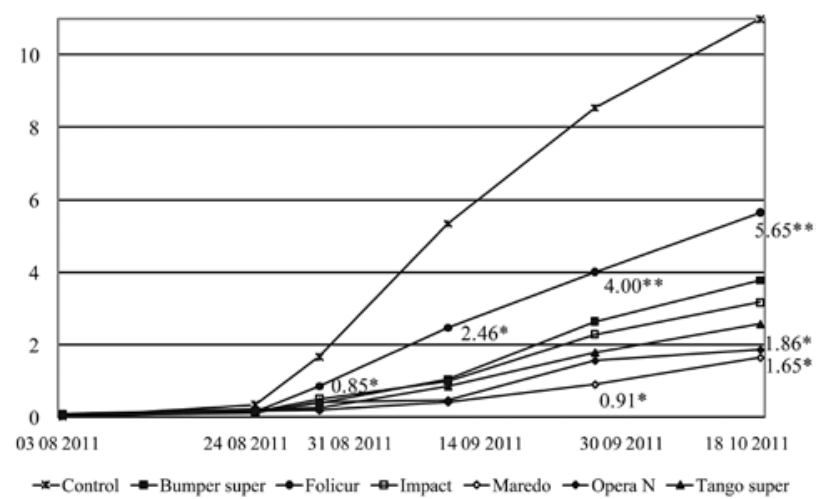

Note. Asterisks denote significant differences from control: *, ** - at $P \leq 0.05$ and $P \leq 0.01$ probability level, respectively.

Figure 2. Cercospora leaf spot severity in sugar beet 'Ernestina', 2011

In 2012, on 31 July ( $1^{\text {st }}$ assessment), before fungicide application cercospora leaf spot had affected $4.3-12.8 \%$ of plants. The disease severity was very low $0.01 \%$ (Fig. 3). Since July and August months were cooler and drier than in 2011, the development of fungal diseases was weaker. A month after fungicide application, the disease severity in unsprayed plots was $0.36 \%$ and in fungicide-applied plots it was $0.05-0.10 \%$.

In September, due to temperature fluctuations (warm days, chilly nights) resulting in the formation of abundant dew, the conditions for the development of cercospora leaf spot improved and the disease severity in the control plots dramatically increased and before harvesting reached $11.91 \%$. In the plots spray-applied with fungicides, at the beginning of October cercospora

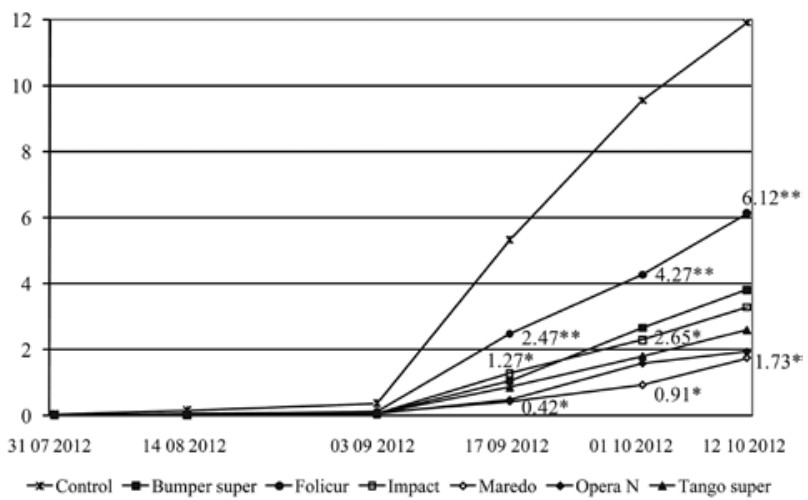

Explanation under Figure 2

Figure 3. Cercospora leaf spot severity in sugar beet 'Ernestina', 2012

leaf spot severity ranged from $0.91 \%$ to $4.27 \%$ and before harvesting it varied from $1.73 \%$ to $6.12 \%$ (depending on the fungicide efficacy). In 2011, one month after fungicide application the fungicide Maredo exhibited the highest efficacy against cercospora leaf spot (Table 1). Its biological efficacy was $88.6 \%$. This fungicide maintained its highest efficacy until harvesting. Similar efficacy was demonstrated by the other two fungicides - Opera $\mathrm{N}$ and Tango super, which contained active ingredient epoxiconazole. Six weeks after spaying, Bumper super (biological efficacy 80.4\%) and Impact (biological efficacy $81.2 \%$ ), remained sufficiently efficient; however, later their efficacy decreased and before harvesting was $65.6 \%$ and $71.2 \%$, respectively. The lowest efficacy against cercospora leaf spot was demonstrated by the fungicide Folicur, whose biological efficacy in 2011 during the entire assessment period was $53.8-48.6 \%$.

In September 2012, the progress of cercospora leaf spot was slow and at the beginning of September the differences between the efficacies of the fungicides had not yet stood out. Six weeks after the spray application, the highest efficacy against cercospora leaf spot was shown by the fungicide Maredo, whose biological efficacy was $92.1 \%$. Like in 2011, this fungicide remained most effective until harvesting. Similar efficacy was exhibited by the fungicide Opera N. The lowest efficacy was recorded for the fungicide Folicur, whose biological efficacy before harvesting was as low as $48.6 \%$.

Table 1. The biological efficacy (\%) of the fungicides used to control cercospora leaf spot in sugar beet 'Ernestina'

\begin{tabular}{|c|c|c|c|c|c|c|c|c|}
\hline \multirow{3}{*}{ Fungicide } & \multicolumn{4}{|c|}{2011} & \multicolumn{4}{|c|}{2012} \\
\hline & \multicolumn{4}{|c|}{ weeks after fungicide application } & \multicolumn{4}{|c|}{ weeks after fungicide application } \\
\hline & 4 & 6 & 8 & 10 & 4 & 6 & 8 & 10 \\
\hline Bumper super & 77.4 & 80.4 & 69.1 & 65.6 & 84.4 & 80.3 & 72.2 & 68.0 \\
\hline Folicur & 48.9 & 53.8 & 53.1 & 48.6 & 71.7 & 53.6 & 55.3 & 48.6 \\
\hline Impact & 69.5 & 81.2 & 73.3 & 71.2 & 87.2 & 76.1 & 76.1 & 72.4 \\
\hline Maredo & 88.6 & 92.1 & 89.4 & 85.0 & 78.6 & 92.1 & 90.4 & 85.4 \\
\hline Opera N & 74.2 & 91.3 & 81.7 & 83.0 & 85.0 & 91.4 & 83.4 & 83.7 \\
\hline Tango super & 84.5 & 84.0 & 79.0 & 76.6 & 85.0 & 84.1 & 81.2 & 78.3 \\
\hline
\end{tabular}

Ramularia leaf spot. In 2011, before spraying ramularia leaf spot had damaged $11.7-25.8 \%$ of the plants, the disease severity was very low and ranged from $0.01 \%$ to $0.04 \%$ (Fig. 4 ).

This disease develops more rapidly in cool weather conditions at an optimal temperature of $17-20^{\circ} \mathrm{C}$
(Asher, Hanson, 2006). In 2011, August was warm, the average daily temperature often exceeded $20^{\circ} \mathrm{C}$, therefore ramularia leaf spot development was slow. One month after fungicide spray application, the disease severity in the control plots was $0.31 \%$, and in the fungicide-applied plots it was $0.03-0.15 \%$. Further in the growing season 


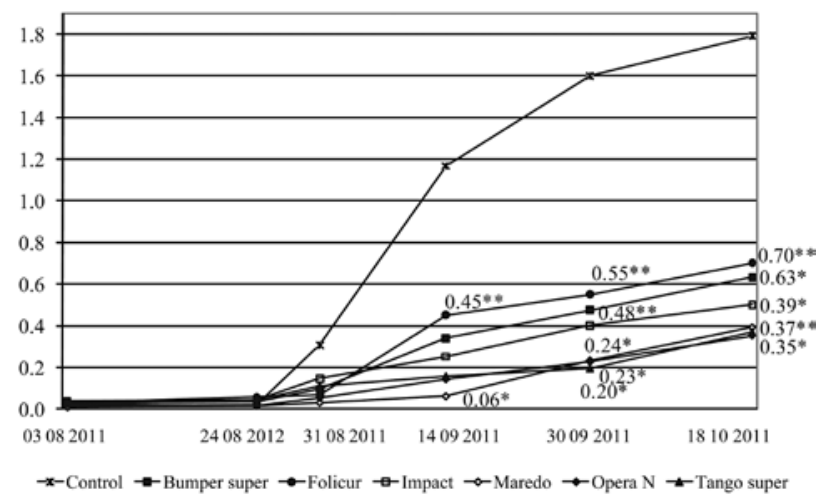

Explanation under Figure 2

Figure 4. Ramularia leaf spot severity in sugar beet 'Ernestina', 2011

ramularia leaf spot severity increased and before harvesting (11 weeks after fungicide application) in the control plots it was $1.79 \%$. In the fungicide-applied plots, ramularia leaf spot severity ranged from $0.35 \%$ to $0.70 \%$.

In 2012, during the $1^{\text {st }}$ assessment ramularia leaf spot had affected a very small sugar beet leaf area and the disease severity was as low as $0.01 \%$ (Fig. 5). One month after fungicide application, the disease severity was also low and amounted to $0.05-0.15 \%$. Before harvesting, ramularia leaf spot severity in the control plots was similar to that in 2011 and amounted to $1.75 \%$. In the plots applied with fungicides, ramularia leaf spot severity varied from $0.36 \%$ to $0.65 \%$.

In 2011, 4-6 weeks after fungicide application Maredo demonstrated the highest efficacy against

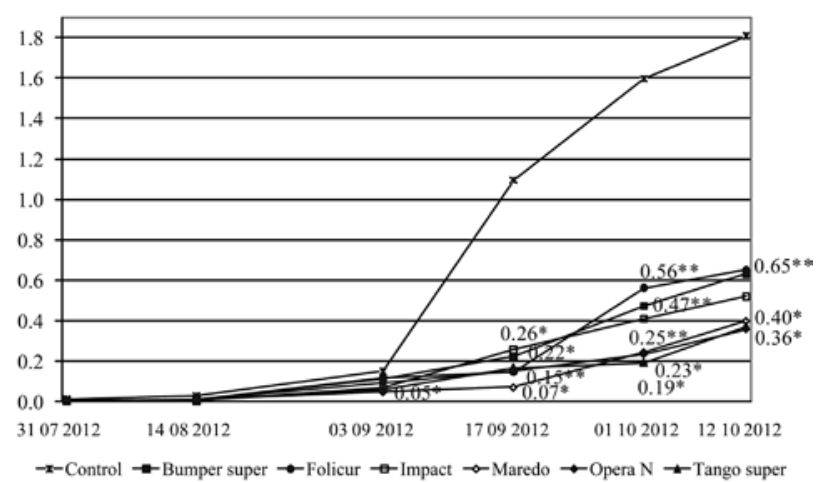

Explanation under Figure 2

Figure 5. Ramularia leaf spot severity in sugar beet 'Ernestina', 2012

ramularia leaf spot. Its biological efficacy was 89.7$94.6 \%$ (Table 2). With advancing growing season, it was declining and at the end of the growing season it was $78.0 \%$. Before harvesting, Opera $\mathrm{N}$ was most effective. The highest ramularia leaf spot damage before harvesting was established in the plots sprayed with the fungicides Folicur and Bumper super.

In 2012, four weeks after fungicide application the highest efficacy was recorded for Maredo and Tango super. These fungicides gave effective protection for plants until harvesting. Six weeks after fungicide application Folicur showed very similar efficacy against ramularia leaf spot. Its biological efficacy was $86.7 \%$. However, with advancing growing season its efficacy decreased and before harvesting it was as low as $64.0 \%$.

Table 2. The biological efficacy (\%) of the fungicides used to control ramularia leaf spot in sugar beet 'Ernestina'

\begin{tabular}{|c|c|c|c|c|c|c|c|c|}
\hline \multirow{3}{*}{ Fungicide } & \multicolumn{4}{|c|}{2011} & \multicolumn{4}{|c|}{2012} \\
\hline & \multicolumn{4}{|c|}{ weeks after fungicide application } & \multicolumn{4}{|c|}{ weeks after fungicide application } \\
\hline & 4 & 6 & 4 & 6 & 4 & 6 & 4 & 6 \\
\hline Bumper super & 69.0 & 71.0 & 70.3 & 64.7 & 25.3 & 79.7 & 70.4 & 65.0 \\
\hline Folicur & 78.7 & 61.4 & 65.6 & 60.9 & 21.3 & 86.7 & 64.8 & 64.0 \\
\hline Impact & 52.6 & 78.5 & 75.0 & 72.1 & 54.7 & 76.6 & 74.4 & 71.2 \\
\hline Maredo & 89.7 & 94.6 & 85.3 & 78.0 & 67.4 & 93.5 & 84.6 & 78.0 \\
\hline Opera N & 82.6 & 87.8 & 85.9 & 80.4 & 37.9 & 86.3 & 85.4 & 80.2 \\
\hline Tango super & 64.5 & 86.6 & 87.8 & 79.5 & 60.0 & 84.7 & 88.0 & 79.5 \\
\hline
\end{tabular}

Yield analysis. Sugar beet root yield was high in both experimental years and ranged from 82.2 to $98.3 \mathrm{t} \mathrm{ha}^{-1}$ (Table 3). In 2011, all fungicides applied against foliar fungal diseases gave a root yield increase. The greatest yield increase (11.8 $\left.\mathrm{t} \mathrm{ha}^{-1}\right)$ was obtained having sprayed with Maredo. This fungicide was the most effective against cercospora leaf spot, which was the most widespread foliar disease. Timely application of Maredo prevented from severe leaf damage, the process of photosynthesis was not disrupted and sugar beet plants produced abundant root yield. The least yield increases were obtained in the plots where the efficacy of the fungicides applied (Bumper super and Folicur) was the lowest. Similar effect of the fungicides was established in 2012.

Table 3. The effect of the fungicides on sugar beet 'Ernestina' root and leaf yield

\begin{tabular}{|c|c|c|c|c|c|c|c|c|c|c|c|c|}
\hline \multirow{3}{*}{ Treatment } & \multicolumn{4}{|c|}{2011} & \multicolumn{4}{|c|}{2012} & \multicolumn{4}{|c|}{ Average } \\
\hline & \multicolumn{2}{|c|}{ root yield } & \multicolumn{2}{|c|}{ leaf yield } & \multicolumn{2}{|c|}{ root yield } & \multicolumn{2}{|c|}{ leaf yield } & \multicolumn{2}{|c|}{ root yield } & \multicolumn{2}{|c|}{ leaf yield } \\
\hline & $\mathrm{t} \mathrm{ha}^{-1}$ & relative & $\mathrm{t} \mathrm{ha}^{-1}$ & relative & $\mathrm{t} \mathrm{ha}^{-1}$ & relative & $\mathrm{t} \mathrm{ha}^{-1}$ & relative & $\mathrm{t} \mathrm{ha}^{-1}$ & relative & $\mathrm{t} \mathrm{ha}^{-1}$ & relative \\
\hline Control (unsprayed) & 82.2 & 100.0 & 58.3 & 100.0 & 84.3 & 100.0 & 64.2 & 100.0 & 83.2 & 100.0 & 61.2 & 100.0 \\
\hline Bumper super & 84.5 & 102.8 & 52.6 & 90.2 & 87.8 & 104.2 & 66.5 & 103.6 & 86.1 & 103.5 & 59.6 & 97.4 \\
\hline Folicur & 86.2 & 104.9 & 56.0 & 96.0 & 83.3 & 98.8 & 58.4 & 91.0 & 84.8 & 101.9 & 57.2 & 93.5 \\
\hline Impact & 87.7 & 106.7 & 57.4 & 98.4 & 98.3 & 116.6 & 69.1 & 107.6 & 93.0 & 111.8 & 63.2 & 103.3 \\
\hline Maredo & 94.0 & 114.4 & 62.5 & 107.2 & 97.5 & 115.6 & 69.7 & 108.6 & 95.7 & 115.0 & 66.1 & 108.0 \\
\hline Opera N & 91.5 & 111.3 & 67.8 & 116.3 & 83.6 & 99.2 & 64.3 & 100.2 & 87.6 & 105.3 & 66.0 & 107.8 \\
\hline Tango super & 93.2 & 113.4 & 61.6 & 105.7 & 98.1 & 116.4 & 69.7 & 108.6 & 95.6 & 114.9 & 65.6 & 107.2 \\
\hline $\mathrm{LSD}_{05}$ & 9.67 & & 9.53 & & 10.00 & & 8.02 & & 7.26 & & 7.98 & \\
\hline
\end{tabular}


Leaf yield in 2011 in different treatments varied from 52.6 to $67.8 \mathrm{t} \mathrm{ha}^{-1}$. The greatest leaf mass was produced in the plots where the efficacy of the fungicides applied was the highest. In the control plots, part of leaves withered because of the diseases. In September the plants started growing new leaves by utilising the nutrients stored in roots. As a result, at harvesting, leaf weight in the control (unsprayed) plots was $58.3 \mathrm{t} \mathrm{ha}^{-1}$, i.e. was greater than in the plots where the efficacy of fungicides applied was low. The lowest leaf yield $\left(52.6 \mathrm{t} \mathrm{ha}^{-1}\right)$ was obtained from the plots sprayed with Bumper super. This fungicide gave a sufficiently good protection against diseases for 5-6 weeks. Later its efficacy declined, the leaves were affected by diseases and the plants failed to produce new leaves before harvesting, which resulted in low yield. In 2012, the weather conditions were favourable for sugar beet biomass growth: in June and July during intensive growing season plants had enough moisture and warmth, while drier weather in August inhibited the spread of foliar diseases. Sugar beet leaf yield was $58.4-69.7 \mathrm{tha}^{-1}$. The most abundant leaf mass was produced by the plants sprayed with Maredo and Tango super. Research conducted at the Rumokai Experimental Station in 2009-2010 established that in 2009 the severity of fungal foliar diseases in sugar-beet crops was low and fungicides used increased root yield by $1.6-6.4 \%$. In 2010 , the incidence of foliar diseases was high and fungicide use gave a root yield increase of 7.4-14.5\% (Braziene, 2011).

Root sugar content in the experimental years varied from $16.81 \%$ to $17.87 \%$ (Table 4 ). This was influenced by the weather conditions and sugar beet protection against foliar diseases. In 2011, when the disease pressure in the sugar beet crops was more severe, all fungicides used gave a significant root sugar content increase. In 2012, statistically significant root sugar content increase, compared with the control plots, was obtained for the treatments sprayed with Bumper super and Maredo. Averaged data suggest that all tested chemical control products, significantly increased sugar content. Averaged data indicated that the highest root sugar content was obtained having sprayed the plots with the fungicide Maredo. White sugar yield is one of the major parameters describing sugar beet yield. It depends not only on root sugar content but also on the noxious substances present in roots (potassium, sodium, and $\alpha$-amino $N$ ) that disturb sugar extraction. $\alpha$-amino $\mathrm{N}$ is the most important one. Its content in roots depends on various factors: nutrient contents present in the soil, mineral fertilization, plant population density, weather conditions, varietal peculiarities, disease prevalence (Hoffman, Märländer, 2005). During the experimental years, $\alpha$-amino $\mathrm{N}$ content in sugar beet roots varied

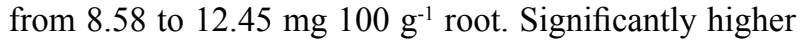
$\alpha$-amino $\mathrm{N}$ content was determined in roots from the control treatment. Chemical control of fungal leaf diseases in sugar beet has been reported to increase sugar content in roots (Gado, 2007). Fungicidal disease control resulted in an increased sugar beet root yield by $1.9-15.10 \%$, root sugar content by $1.6-3.6 \%$, white sugar yield by $5.0-21.4 \%$.

Table 4. The effect of the fungicides on sugar content in sugar beet 'Ernestina' roots

\begin{tabular}{|c|c|c|c|c|c|c|c|c|c|c|c|c|}
\hline \multirow{3}{*}{ Treatment } & \multicolumn{4}{|c|}{2011} & \multicolumn{4}{|c|}{2012} & \multicolumn{4}{|c|}{ Average } \\
\hline & \multicolumn{2}{|c|}{ sugar content } & \multicolumn{2}{|c|}{$\alpha$-amino $\mathrm{N}$} & \multicolumn{2}{|c|}{ sugar content } & \multicolumn{2}{|c|}{$\alpha$-amino $\mathrm{N}$} & \multicolumn{2}{|c|}{ sugar content } & \multicolumn{2}{|c|}{$\alpha$-amino $\mathrm{N}$} \\
\hline & $\%$ & relative & $\begin{array}{c}\mathrm{mg} \\
100 \mathrm{~g}^{-1}\end{array}$ & relative & $\%$ & relative & $\begin{array}{c}\mathrm{mg} \\
100 \mathrm{~g}^{-1}\end{array}$ & relative & $\%$ & relative & $\begin{array}{c}\mathrm{mg} \\
100 \mathrm{~g}^{-1}\end{array}$ & relative \\
\hline $\begin{array}{l}\text { Control } \\
\text { (unsprayed) }\end{array}$ & 16.81 & 100.0 & 12.10 & 100.0 & 17.68 & 100.0 & 12.45 & 100.0 & 17.25 & 100.0 & 12.28 & 100.0 \\
\hline Bumper super & 17.46 & 103.9 & 9.25 & 76.4 & 18.03 & 102.0 & 8.65 & 69.5 & 17.75 & 102.9 & 8.95 & 72.9 \\
\hline Folicur & 17.28 & 102.8 & 9.53 & 78.7 & 17.78 & 100.6 & 9.93 & 79.8 & 17.53 & 101.6 & 9.73 & 79.2 \\
\hline Impact & 17.47 & 103.9 & 10.40 & 86.0 & 17.89 & 101.2 & 8.60 & 69.1 & 17.68 & 102.5 & 9.50 & 77.4 \\
\hline Maredo & 17.59 & 104.6 & 9.55 & 78.9 & 18.16 & 102.7 & 8.98 & 72.1 & 17.87 & 103.6 & 9.26 & 75.4 \\
\hline Opera N & 17.59 & 104.6 & 9.18 & 75,9 & 17.71 & 100.2 & 8.58 & 68.9 & 17.65 & 102.3 & 8.88 & 72.3 \\
\hline Tango super & 17.52 & 104.2 & 8.90 & 73,6 & 17.97 & 101.6 & 10.05 & 80.7 & 17.74 & 102.8 & 9.48 & 77.2 \\
\hline $\mathrm{LSD}_{05}$ & 0.339 & & 2.324 & & 0.341 & & 2.795 & & 0.247 & & 1.800 & \\
\hline
\end{tabular}

Table 5. The effect of the fungicides on white sugar yield in sugar beet 'Ernestina'

\begin{tabular}{|c|c|c|c|c|c|c|c|c|c|}
\hline \multirow{3}{*}{ Treatment } & \multicolumn{3}{|c|}{2011} & \multicolumn{3}{|c|}{2012} & \multicolumn{3}{|c|}{ Average } \\
\hline & \multicolumn{2}{|c|}{$\begin{array}{l}\text { white sugar } \\
\text { yield }\end{array}$} & yield increase & \multicolumn{2}{|c|}{$\begin{array}{l}\text { white sugar } \\
\text { yield }\end{array}$} & yield increase & \multicolumn{2}{|c|}{$\begin{array}{c}\text { white sugar } \\
\text { yield }\end{array}$} & yield increase \\
\hline & $\mathrm{t} \mathrm{ha}^{-1}$ & relative & t ha $^{-1}$ & $\mathrm{tha}^{-1}$ & relative & $\mathrm{t} \mathrm{ha}^{-1}$ & $\mathrm{t} \mathrm{ha}^{-1}$ & relative & $\mathrm{t} \mathrm{ha}^{-1}$ \\
\hline $\begin{array}{l}\text { Control } \\
\text { (unsprayed) }\end{array}$ & 11.51 & 100.0 & - & 12.43 & 100.0 & - & 11.97 & 100.0 & - \\
\hline Bumper super & 12.49 & 108.5 & 0.98 & 13.54 & 108.9 & 1.11 & 13.02 & 108.8 & 1.05 \\
\hline Folicur & 12.54 & 108.9 & 1.03 & 12.60 & 101.4 & 0.17 & 12.57 & 105.0 & 0.60 \\
\hline Impact & 12.89 & 112.0 & 1.38 & 14.97 & 120.4 & 2.54 & 13.93 & 116.4 & 1.96 \\
\hline Maredo & 13.91 & 120.9 & 2.40 & 15.16 & 122.0 & 2.73 & 14.53 & 121.4 & 2.56 \\
\hline Opera N & 13.69 & 118.9 & 2.18 & 12.54 & 100.9 & 0.11 & 13.11 & 109.5 & 1.14 \\
\hline Tango super & 13.79 & 119.8 & 2.28 & 14.93 & 120.1 & 2.50 & 14.36 & 120.0 & 2.39 \\
\hline $\mathrm{LSD}_{05}$ & 1.305 & & & 1.598 & & & 1.029 & & \\
\hline
\end{tabular}


During the research years, white sugar yield fluctuated from 11.51 to $14.97 \mathrm{t} \mathrm{ha}^{-1}$ (Table 5). The data averaged over two years indicate that all fungicides applied, except for Folicur, gave a significant white sugar yield increase, compared with the control treatment. The highest white sugar yield was obtained having sprayed the sugar beet plants with the fungicide Maredo. Research conducted at the Rumokai Experimental Station in 2009-2010 established that foliar disease control increased sugar content in roots in 2010 when, due to the use of a fungicide, sugar content increased by $2.2-14.5 \%$ (Brazienè, 2011).

\section{Conclusions}

1. During the experimental years, the first symptoms of leaf diseases in sugar beet crops started to appear on 31 July-3 August. After 10-11 weeks from the beginning of assessments, the cercospora leaf spot had damaged $90.0-98.3 \%$ of plants and the disease severity was $10.98-11.91 \%$ in the plots where fungicides had not been applied. Ramularia leaf spot severity was lower than that of cercospora leaf spot, and before sugar beet harvesting ramularia leaf spot severity reached $1.75-$ $1.79 \%$ in untreated plots.

2. The fungicides containing active ingredient (a.i.) epoxiconazole exhibited the highest efficacy in controlling cercospora leaf spot and ramularia leaf spot pathogens.

3. All the tested fungicides applied to control foliar fungal diseases on sugar beet crops gave root yield, sugar content and white sugar yield increases. The greatest yield increases were obtained having sprayed the crop with the fungicide Maredo (a.i. epoxiconazole).

4. Fungicides significantly decreased the content of $\alpha$-amino $\mathrm{N}$ in roots. The lowest content of $\alpha$-amino $\mathrm{N}$ in roots was determined having sprayed the crop with the fungicide Opera N, containing two active ingredients pyraclostrobin and epoxiconazole.

Received 17092012 Accepted 11092013

\section{References}

Asher M. J. C., Hanson L. E. 2006. Fungal and bacterial diseases. Draycot A. P. (ed.). Sugar beet. Oxford, UK, p. $286-315$

Bălău A. M., Irimia N. 2010. Epidemic evolution of Cercosppora leaf spot (Cercospora beticola Sacc.) under Ezareni farm conditions. Revista Lucrări ştiinţifice, seria Agronomie, 53 (1): $184-186$

Barlett D. W., Clough J. M., Godwin J. R., Halle A. A., Hamer M., Parr-Dobzanski. 2002. The strobilurin fungicides. Pest Management Science, 58: 649-662 http://dx.doi.org/10.1002/ps.520

Brazienè Z. 2011. The effect of fungal diseases and harvesting timing on sugar-beet productivity. Žemès ūkio mokslai, 18 (2): 47-52 (in Lithuanian)

Briere S. C., Franc G. D., Kerr E. D. 2003. Fungicide sensitivity characteristics of Cercospora beticola isolates recovered from the High Plains of Colorado, Montana, Nebraska and Wyoming. 2. Mancozeb, propiconazole and azoxystrobin. Journal of Sugar Beet Research, 40: 53-65 http://dx.doi.org/10.5274/jsbr.40.1.53
Boten G. N., Šikalčik N. V. 2001. Reks - effektivnyi fungicid $\mathrm{v}$ borbe $\mathrm{s}$ tserkosporozom sakharnoi svyokly. Zashchita rastenii na rubezhe XXI veka: materialy nauchnoprakticheskoi konferencii. Minsk, p. 166-168 (in Russian)

Deveikytė I., Petkevičienė B., Kaunas J. 2009. Sugar beet: agrobiology, research, technologies (in Lithuanian)

Dutton J., Huijbregts T. 2006. Root quality and processing. Draycot A. P. (ed.). Sugar beet. Oxford, UK, p. 409-442

EPPO Standards. 2004. Efficacy Evaluation of Fungicides and Bactericides, vol. 2

Gado E. A. M. 2007. Management of cercospora leaf spot disease of sugar beet plants by some fungicides and plant extract. Egyptian Journal of Phytopathology, 35 (2): 1-10

Gaurilčikienė I., Deveikytė I., Petraitienė E. 2006. Epidemic progress of Cercospora beticola Sacc. in Beta vulgaris L. under different conditions and cultivar resistance. Biologija, 4: 54-59

Hoffman Ch., Märländer B. 2005. Composition of harmful nitrogen in sugar beet (Beta vulgaris L.) - amino acids, nitrate - as affected by genotype and environment. European Journal of Agronomy, 22 (3): 255-265 http://dx.doi.org/10.1016/j.eja.2004.03.003

Jacobsen B. J., Franc G. D. 2009. Cercospora leaf spot. Compendium of beet diseases and pests ( $2^{\text {nd }} e d$.). Harveson R. M. et al. (eds). St. Paul, USA, p. 7-10

Karaoglanidis G. S., Bardas G. 2006. Control of benzimidazoleand DMI-resistant strains of Cercospora beticola with strobilurin fungicides. Plant Disease, 90 (4): 419-424 http://dx.doi.org/10.1094/PD-90-0419

Karaoglanidis G. S., Ioannidis P. M. 2010. Fungicide resistance of Cercospora beticola in Europe. Lartey R. T. et al. (eds). Cercospora leaf spot of sugar beet and related species, p. $189-211$

Khan J., del Tio L. E., Nelson R., Rivera-Varas V., Secor G. A., Khan M. F. R. 2008. Survival, dispersal and primary infection site for Cercospora beticola in sugar beet. Plant Disease, 92 (5): 741-745 http://dx.doi.org/10.1094/PDIS-92-5-0741

Khan M. F. R., Smith L. J. 2005. Evaluating fungicides for controlling Cercospora leaf spot on sugar beet. Crop Protection, 24: 79-86 http://dx.doi.org/10.1016/j.cropro.2004.06.010

Korol A. L., Preičerzon V. A. 1990. Statisticheskaya otsenka biologicheskoi effektivnosti preparata $\mathrm{s}$ pomoshchyu EVM. Zashchita rastenii, 10: 22-23 (in Russian)

Malandrakis A. A., Markoglou A. N., Nikou D. C., Vontas J. G., Ziogas B. N. 2011. Molecular diagnostic for detecting the citochrome b G1435-Qol resistance mutation in Cercospora beticola. Pesticide Biochemistry and Physiology, p. 87-92 http://dx.doi.org/10.1016/j.pestbp.2011.02.011

Petersen J., Adams H., Shaufelle W. R., Buttner G. 2001. Untersuchungen zur Schadwirkung von Ramularia beticola in Zuckerruben und Möglichkeiten zur Differenzierung der Sortenanfalligkeit nach künstlicher Inokulation. Gezunde Pflanzen, 53 (5): 141-147 (in German)

Petkevičienè B., Kaunas J. 2004. Influence of natural conditions on the prevalence of cercospora leaf spot (Cercospora beticola Sacc.) and ramularia leaf spot (Ramularia beticola Fant \& Lamb.) in different varieties of sugar beet. Žemès ūkio mokslai, 4: 28-35 (in Lithuanian)

Secor G. A., Rivera V. V., Khan M. F. R., Gudmestad N. C. 2010. Monitoring fungicide sensitivity of Cercospora beticola of sugar beet for disease management decisions. Plant Disease, 94 (11): 1272-1282 http://dx.doi.org/10.1094/PDIS-07-09-0471 
Statistics Lithuania. 2012. Crops and yields of Agriculture. $<$ http://web.stat.gov.lt/lt/news/view/?id=11921\&PHPSE $\mathrm{SSID}=\mathrm{d} 24 \mathrm{~d} 95 \mathrm{fb} 48 \mathrm{ccca} 5 \mathrm{~b} 4 \mathrm{ab} 0996 \mathrm{eded} 27242>$ [accessed 0725 2013] (in Lithuanian)

Tarakanovas P., Raudonius S. 2003. Agronominių tyrimų duomenu statistinè analizè taikant kompiuterines programas ANOVA, STAT, SPLIT-PLOT iš paketo SELEKCIJA ir IRRISTAT. Lithuanian University of Agriculture (in Lithuanian)

Vereijssen J. 2007. Supervised control of Cercospora leaf spot in sugar beet. Crop Protection, 26 (1): 19-28 http://dx.doi.org/10.1016/j.cropro.2006.03.012

Vereijssen J., Schneider J. H. M., Termorshuizen A. J., Jeger M. J. 2003. Comparison of two disease assessment methods for assessing Cercospora leaf spot in sugar beet. Crop Protection, 22 (1): 201-209

http://dx.doi.org/10.1016/S0261-2194(02)00146-1
Vereijssen J., Schneider J. H. M., Termoshuizen A. J. 2005. Root infection of sugar beet by Cercospora beticola in a klimate chamber and in the field. European Journal of Plant Pathology, 112 (3): 201-210 http://dx.doi.org/10.1007/s10658-004-4172-y

Weiland J., Koch G. 2004. Sugar beet leaf spot disease (Cercospora beticola Sacc.). Molecular Plant Pathology, 5 (3): $157-166$ http://dx.doi.org/10.1111/j.1364-3703.2004.00218.x

Wolf P. F. J., Verreet J. 2002. An integrated pest management system in Germany for the control of fungal leaf diseases in sugar beet: the IPM sugar beet models. Plant Disease, 86(4): 336-344 http://dx.doi.org/10.1094/PDIS.2002.86.4.336

ISSN 1392-3196 / e-ISSN 2335-8947

Zemdirbyste-Agriculture, vol. 100, No. 4 (2013), p. 401-408

DOI $10.13080 / \mathrm{z}-\mathrm{a} .2013 .100 .051$

\title{
Rudmargès (Cercospora beticola Sacc.) ir baltulių (Ramularia beticola Fautrey \& F.Lamb.) plitimo dinamika bei kontrolè cukrinių runkelių pasẻliuose
}

\author{
M. Baltaduonytè ${ }^{1}$, Z. Dabkevičius ${ }^{1,2}$, Z. Braziené², E. Surviliené2 \\ ${ }^{1}$ Aleksandro Stulginskio universitetas, Lietuva \\ ${ }^{2}$ Lietuvos agrarinių ir miškų mokslų centras
}

\section{Santrauka}

Lietuvos agrarinių ir miškų mokslų centro Rumokų bandymų stotyje 2011-2012 m. tirta žalingiausių cukrinių runkelių lapų ligų rudmargès bei baltulių plitimo dinamika ir cheminių apsaugos produktų nuo šių ligų efektyvumas. Tyrimų metu naudoti fungicidai Bumper super (veiklioji medžiaga (v. m.) prochlorazas $400 \mathrm{~g} \mathrm{l}^{-1}+$ propikonazolas $90 \mathrm{~g} \mathrm{l}^{-1}$ ) 1,0 $1 \mathrm{ha}^{-1}$, Folicur (v. m. tebukonazolas $250 \mathrm{~g} \mathrm{l}^{-1}$ ) 1,0 $1 \mathrm{ha}^{-1}$, Impact (v. m. flutriafolas $250 \mathrm{~g} \mathrm{l}^{-1}$ ) $0,25 \mathrm{l} \mathrm{ha}^{-1}$, Maredo (v. m. epoksikonazolas $125 \mathrm{~g} \mathrm{l}^{-1}$ ) 1,0 $\mathrm{l} \mathrm{ha}^{-1}$, Opera N (v. m. piraklostrobinas $85 \mathrm{~g} \mathrm{l}^{-1}+$ epoksikonazolas 62,5 $\mathrm{g} \mathrm{l}^{-1}$ ) 0,8 $1 \mathrm{ha}^{-1}$ ir Tango super (v. m. fenpropimorfas $250 \mathrm{~g} \mathrm{l}^{-1}+$ epoksikonazolas $84 \mathrm{~g} \mathrm{l}^{-1}$ ) 1,5 1 ha $^{-1}$. Pasèlis fungicidais purkštas vieną kartą, pradèjus plisti lapų ligoms.

Tyrimų metais rudmargè cukrinių runkelių pasėliuose pradejjo plisti liepos 31 - rugpjūčio 3 dienomis. Pirmosios apskaitos metu ši liga buvo pažeidusi 4,3-19,2 \% augalų, ligos intensyvumas buvo 0,01-0,08 \%. Rudmargès tolesniam plitimui turèjo ịtakos meteorologinès sąlygos: esant drėgniems ir šiltiems orams, liga sparčiai vystèsi ir praejus 10-11 savaičių nuo stebejjimo pradžios buvo pažeidusi 90,0-98,3 \% augalų, o jos intensyvumas siekè $10,98-11,91 \%$. Baltuliai pradejo plisti tuo pačiu metu kaip ir rudmargè, tačiau ligos intensyvumas buvo mažesnis - pirmosios apskaitos metu siekė $0,1-0,4 \%$. Ši liga vystėsi lèčiau nei rudmargè, ir prieš cukrinių runkelių derliaus nuẻmimą baltulių intensyvumas siekè $1,75-1,79 \%$. Nuo šių ligų efektyviausiai veikè fungicidai, kurių sudètyje buvo veiklioji medžiaga epoksikonazolas, t. y. Maredo, Opera N ir Tango super. Jų biologinis efektyvumas buvo 78,3-85,4 \%. Taikant cheminę ligų kontrolę, cukrinių runkelių šakniavaisių derlius padidejo nuo 1,9 iki 15,1\%, šakniavaisių cukringumas - nuo 1,7 iki $3,7 \%$, baltojo cukraus derlius - nuo 5,0 iki 21,4 \%.

Reikšminiai žodžiai: Cercospora beticola, cukraus išeiga, cukriniai runkeliai, derlius, fungicidai, Ramularia beticola. 